\title{
Second record of bioluminescence in larvae of Xantholinus Dejean (Staphylinidae, Xantholinini) from Brazil
}

\author{
Simone Policena Rosa ${ }^{1}$
}

${ }^{1}$ Museu de Zoologia da Universidade de São Paulo. Caixa Postal 42494, 04218-970 São Paulo-SP, Brazil. simonepr@usp.br

\begin{abstract}
Second record of bioluminescence in larvae of Xantholinus Dejean, (Staphylinidae, Xantholinini) from Brazil. Bioluminescent Xantholinus larvae (Xantholinini, Staphylinidae) were collected in the Cerrado biome of Mato Grosso state, Brazil. These larvae are morphologically similar to the first bioluminescent larvae of this genus collected in the Atlantic Forest in São Paulo state; however they differ by their bioluminescent emission.
\end{abstract}

KEYWORDS. Firefly; luminescence; Neotropical; new record; region.

RESUMO. Segundo registro de bioluminescência em larvas de Xantholinus Dejean (Staphylinidae, Xantholinini) do Brasil. Larvas de Xantholinus sp. (Xantholinini, Staphylinidae) foram coletadas no Cerrado do estado do Mato Grosso. Essas larvas são similares às primeiras larvas bioluminescentes do mesmo gênero coletadas na Floresta Atlântica em São Paulo, mas diferem pela emissão da bioluminescência.

PALAVRAS-CHAVE. Luminescência; novo registro; região Neotropical; vaga-lumes.

The presence of bioluminescence in Coleoptera is well known in the families Elateridae, Phengodidae, Rhagophthalmidae and Lampyridae (Elateroidea) and was also recorded at least once in the small elateroid family Omalisidae and in Staphylinidae. The larval bioluminescence of Omalisus fontisbellaquaei Geoffroy, 1785 (Omalisidae) was recorded by Bertkau (1891), and since then it has not been observed, despite some authors have regarded it as bioluminescent or bearing photic organs (Crowson 1972; Lawrence 1991; Branham \& Wenzel 2001, 2003). Burakowski (1988) collected four larvae of those species, reared them on laboratory during the period of 3 to 11 months and affirmed that he never saw those larvae emitting bioluminescence.

Costa et al. (1986) described the morphology and bioluminescence of Staphylinidae larvae, identified as Xantholinus sp. (Xantholinini, Staphylinidae) based on Böving \& Craighead (1931) and Prins (1984). These larvae were collected in July and December 1983 and December 1984, at the preserved area of Atlantic Forest "Estação Biológica de Boracéia", in Salesópolis, São Paulo state, Brazil. The larvae were walking fast on the surface of the soil when collected. In the laboratory conditions, they died during moulting. This was the first record in literature of bioluminescence in the family Staphylinidae, but they had already been observed 13 years before in November, in the same locality (Costa et al. 1986).

In the present work it is reported the first occurrence of the Xantholinus sp. bioluminescent larvae in Mato Grosso state, Brazil, including field and laboratory observations. These data are supposed to encourage future researches concerning this rare bioluminescent beetle. The material studied is deposited in the "Coleção de Larvas do Museu de Zoologia da Universidade de São Paulo" (Brazil - Mato Grosso: Chapada dos Guimarães, $15^{\circ} 26^{\prime} 51.64^{\prime \prime} \mathrm{S}, 55^{\circ} 38^{\prime} 36.26^{\prime \prime} \mathrm{W}$, 730 m, 1-14.XI.2008, S. P. Rosa, F. Fernandes, R. Kawada \& J. Almeida col., 1 larva, 1 larval exuvia, 1 pupa ).

The genus Xantholinus comprises ca. 274 species and is found in all zoogeographic regions (Herman 2001). The immature stages of the majority of the species are unknown. Therefore, at the present moment, it is not possible to identify the species based only on its larvae.

The technique for collecting soil-burrowing coleopteran larvae consisted of soil excavation using gardening equipments. The search for specimens was made up to $c a$. $50 \mathrm{~cm}$ depth, nevertheless the majority of the larvae were found in the superficial layer with the maximum depth of approximately $10 \mathrm{~cm}$. The collected larvae were placed inside plastic jars containing a sample of soil and kept into icebox to be transported to the laboratory under low temperature.

In the laboratory, the bioluminescent staphylinid larvae were fed with termite workers and the soil was moistened twice a week. Bioluminescence observations were made to the naked eye and under stereomicroscope, at night, between 19 and 21 o'clock. The larvae were identified as Xantholinus sp. following Costa et al. (1988) and were directly compared to the voucher specimens of Costa et al. (1986), which are deposited in the "Coleção de Larvas do Museu de Zoologia da Universidade de São Paulo"

The two larvae of Xantholinus sp. were collected in early November in a private preserved area contiguous with a 
soybean plantation, to the east of the "Parque Nacional da Chapada dos Guimarães". This area, called "cerradão", has a forest physiognomy and litter deposition. The larvae were collected in the superficial layer of the soil with the maximum depth of $10 \mathrm{~cm}$, around a termite nest $c a .1 \mathrm{~m}$ height, placed in the border of the "cerradão" vegetation and in front of the soybean plantation.

In that area were found also larvae belonging to species of Scarabaeidae, Phrixotrix (Phengodidae), Conoderini and Pyrophorini (Elateridae), Morionini (Carabidae) and another unidentified Staphylinidae. Several termites (Velocitermes spp., Dentispicotermes sp. and Nasutitermes sp.) and diplopods were observed around and inside the termite nest. Both Pyrophorini and Phengodidae comprise bioluminescent species.

The first observation of the bioluminescence in the Xantholinus sp. larvae from Mato Grosso was made in the field, at night, a week before its transportation to the laboratory. In that occasion, the larvae emitted an intense green-bluish bioluminescence apparently from all over the dorsal face of the body. It was not possible to identify which segments emitted the light.

In the laboratory, the bioluminescence was observed several times, but day by day the intensity of the light emission decreased. During the first laboratory observation, the larvae emitted green-bluish light on the dorsal median line from the pronotum up to $8^{\text {th }}$ abdominal segment. It was not possible to verify if the $9^{\text {th }}$ segment emitted light as well because the larvae always had this segment curved ventrally. The light of the pronotum was more intense than the other body parts. After two weeks, the bioluminescence become weak and green. The larvae glowed only after being much disturbed and the tiny light could be observed only in the complete darkness.

Three weeks after its collection, one larva pupated but died with the larval exuvia still attached to the head. After $c a$. 52 days, the abdomen of the other larva became dilated and it died. These later had the exuvial dorsal line weakened and expanded which suggests that it was in moulting process. It is noticeable that the larvae reared in this work, as well as those of Costa et al. (1986), despite keep on very agile and eating termites, died during moulting.

The larvae from Mato Grosso have no significant morphological differences when compared to the larvae described by Costa et al. (1986) and both do not present luminous organs externally visible. However, they differ by the bioluminescence emission. The larvae from Mato Grosso emitted light on the dorsal median line from the prothorax up to at least $8^{\text {th }}$ abdominal segment, with the colour greenbluish or green to the naked eyes, being the pronotal light stronger than the others. The larvae of Costa et al. (1986) emitted bioluminescence on the $8^{\text {th }}$ abdominal segment with mean peak wavelength of approximately $568 \mathrm{~nm}$, which correspond to the greenish-yellow colour observed to the naked eyes.

In the present work it is reaffirmed the presence of bioluminescence in the Staphylinidae genus Xantholinus. Nevertheless, several questions remain. New specimens of the Xantholinus sp. from Mato Grosso should be collected to have their bioluminescent spectra precisely recorded. Both specimens, from Mato Grosso and São Paulo, should be reared until adult stage to be identified at the species level as well as to investigate the function and the source of their bioluminescence, that is, if they have organs to produce bioluminescence or if it is a result of mutualism or infection. Finally, and maybe first of all, in order to rear successfully those larvae, it is required an investigation of their habits and nutritional requirements.

Acknowledgements. I am grateful to Ricardo Kawada (MZSP) by helping in the collection, to Tiago Carrijo (MZSP) by confirming the bioluminescence colour in the laboratory, to Eliana M. Cancello (MZSP) by identification of the termites, to Cleide Costa (MZSP) and to anonymous reviewers by corrections and suggestions and to Fundação de Amparo à Pesquisa no Estado de São Paulo (FAPESP) by the grant for supervised research by Cleide Costa (Proc. 07/59294-2) and by author's grant (Proc. 07/56202-0).

\section{REFERENCES}

Bertkau, P. 1891. Beschreibung der Larve and des Weibchen von Homalisus suturalis. Deutsche Entomologische Zeitschrift 1891: 37-42

Böving, A. G. \& F. C. Craighead. 1931. An illustrated synopsis of the principal larval forms of the order Coleoptera. Entomologica Americana 11: $1-351$

Branham, M. A. \& J. W. Wenzel. 2001. The evolution of bioluminescence in cantharoids (Coleoptera: Elateriodea). Florida Entomologist 84: $565-586$.

Branham, M. A. \& J. W. Wenzel. 2003. The origin of photic behavior and the evolution of sexual communication in fireflies (Coleoptera: Lampyridae). Cladistics 19: 1-22.

Burakowski, B. 1988. Observations on the larval morphology and biology of Omalisus fontisbellaquei Fourcroy (Coleoptera, Homalisidae). Bulletin Entomologique de Pologne 58: 571-574.

Costa, C.; S. A. Vanin \& P. Colepicolo Neto. 1986. Larvae of Neotropical Coleoptera. XIV. First Record of Bioluminescence in the family Staphylinidae (Xantholinini). Revista Brasileira de Entomologia 30: 101-104.

Costa, C.; S. A. Vanin \& S. A. Casari-Chen. 1988. Larvas de Coleoptera do Brasil. São Paulo, Museu de Zoologia, vii + 282 p.

Crowson, R. A. 1972. A review of the classification of the Cantharoidea (Coleoptera), with the definition of two new families, Cneoglossidae and Omethidae. Revista de la Universidad de Madrid 21: 35-77.

Herman, L. H. 2001. Catalog of the Staphylinidae (Insecta: Coleoptera). Part VI. Bulletin of the American Museum of Natural History 265: 3021-3840.

Lawrence, J. F. 1991. Homalisidae (Cantharoidea), p. 422-423. In: F. W. Stehr (ed.). Immature Insects 2. Dubuque, Kendal/Hunt Publishing Company, $975 \mathrm{p}$.

Prins, A. J. 1984. Morphological and biological notes on some South African arthropods associated with decaying organic matter. Part 2. The predatory families Carabidae, Hydrophilidae, Histeridae, Staphylinidae and Silphidae (Coleoptera). Annals of the South African Museum 92: 295-356.

Received 29/04/2009; accepted 30/12/2009 